\title{
Role of Laparoscopy in Appendicular Mass among Pediatric Age Group With or Without Perforation: Early Outcome
}

\author{
SAMIR M. ABO EL-SOOD, M.Sc.; SHERIF M. SHEHATA, M.D.; HOSSAM F. HASSAN, M.D. and \\ HISHAM AL-ALMETAHER, M.D.
}

The Department of General Surgery, Faculty of Medicine, Tanta University

\begin{abstract}
Background: Laparoscopic appendectomy is a safe, feasible and effective technique for complicated appendicitis such as mass, abscess and perforation in pediatric patients. Laparoscopic approach had several advantages over open appendectomy in that, it allow proper and wide visualization of the abdominal cavity.

Aim: Our aim is to evaluate the feasibility and safety of laparoscopy in cases of appendicular mass among pediatric age group with or without perforation.

Material and Methods: This study was carried out on fourty children presented by complicated appendicitis (perforation, mass or abscess) with history less than 72 hours, aged between 4 and 18 years and scheduled for laparoscopic appendectomy. Antibiotic regimen consisted of daily intravenous administration of (cefotiam, $80 \mathrm{mgkg} / 24 \mathrm{~h}$ ) for 5 days intravenously and metronidazole $(20 \mathrm{mg} / \mathrm{kg} / 24 \mathrm{~h})$ for 5 days intravenously, oral antibiotics (cefuroxime + metronidazole) were continued for another 1 week.

Results: Intraoperative findings were 17 cases acute perforated appendicitis, 13 cases appendicular mass, two patients were converted to open appendectomy. Analysis revealed presence of gangrenous appendicitis in $75 \%$ and suppurative (Phlegmonous) appendicitis in $25 \%$ of all appendices. Post-operative complications were encountered in form of intraperitoneal collection in one, fever in five, umbilical port site infection in two cases.

Conclusions: Laparoscopic appendectomy is a safe, feasible and effective technique for complicated appendicitis such as mass, abscess and perforation in pediatric patients. Laparoscopic approach had several advantages over open appendectomy in that, it allow proper and wide visualization of the abdominal cavity, moreover, it is very useful in reaching an exact diagnosis in complicated cases with experience and gentle handling.
\end{abstract}

Key Words: Laparoscopic appendectomy-Complicated appendicitis - Pediatrics.

Correspondence to: Dr. Samir M. Abo El-Sood,

The Department of General Surgery, Faculty of Medicine, Tanta University

\section{Introduction}

ACUTE appendicitis is the most common pediatric abdominal surgical emergency [1]. The classic open appendectomy described by McBurney in the 19 th century has been gradually replaced by the laparoscopic appendectomy first performed by Kurt Semm in 1983 [1]. Due to the development and gradual adjustment in size of the laparoscopic instruments, this technique started to be used in pediatric surgery as well in the 90 s.

Laparoscopic appendectomy has the advantages of providing better access and good visualization of the peritoneal cavity with relatively smaller incisions, decreasing the length of hospitalization, there are fewer parietal wall complications, lower percentage of bowel obstruction, faster restoration of the gastrointestinal transit, lower need for antibiotics and analgesics, better cosmetic results and faster reintegration in the normal daily life [2] as compared to open appendectomy but the place of laparoscopy in complicated appendicitis in children still remains a matter of debate [3].

The percentage of post laparoscopy mechanical bowel obstruction is lower due to smaller wall incisions, atraumatic instruments and better irrigation of the entire abdominal cavity under direct view. Intestinal transit is restored sooner due to atraumatic handling of the intestinal loops and immediate postoperative mobilization of the patient. All these benefits are even more evident in obese patients [4].

\section{Aim and objectives:}

The aim of this study is to evaluate the feasibility and safety of laparoscopic appendectomy in cases of complicated appendicitis among pediatric age group. 


\section{Material and Methods}

A prospective randomized study was carried out in Tanta University Hospitals in Pediatric Surgery Unit (A) in the period between July 2015 and January 2017, on fourty children of both sex presented by complicated appendicitis (perforation, mass) with history less than 72 hours, aged between 4 and 18 years and scheduled for laparoscopic

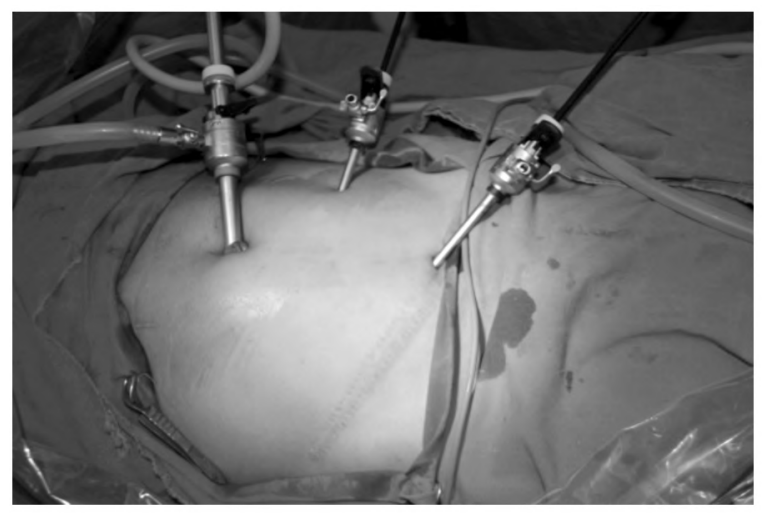

Fig. (1): Ports placement in appendectomy.

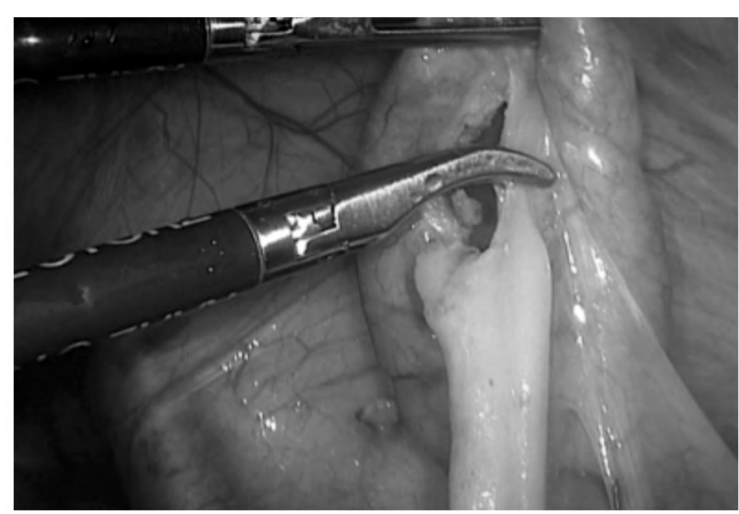

Fig. (3): Appendix devascularization using diathermy.

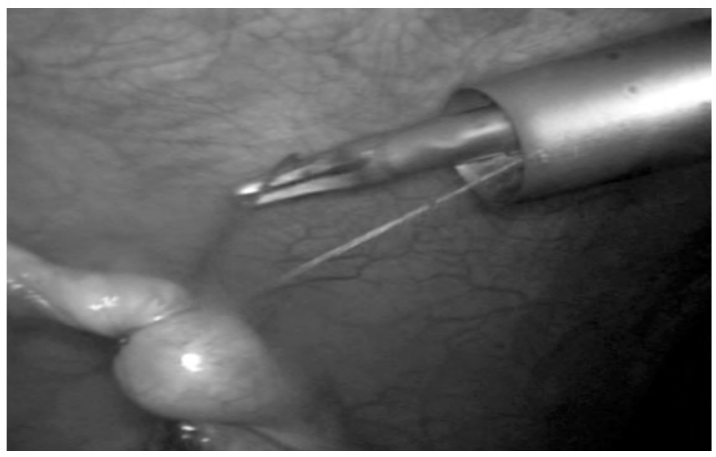

Fig. (5): Ligation of the first knot extracorporeally at the base of the appendix. appendectomy and patients aged more than 18 years and patients with history of acute appendicitis more than 72 hours were excluded patients were subjected to the following, full history taking, general examination, local examination, investigations.

Surgical technique, is shown in the following Figures.

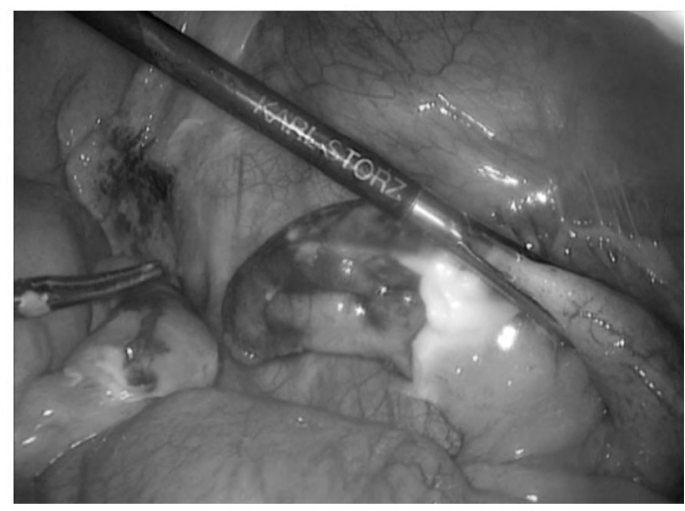

Fig. (2): Appendix held with forceps.

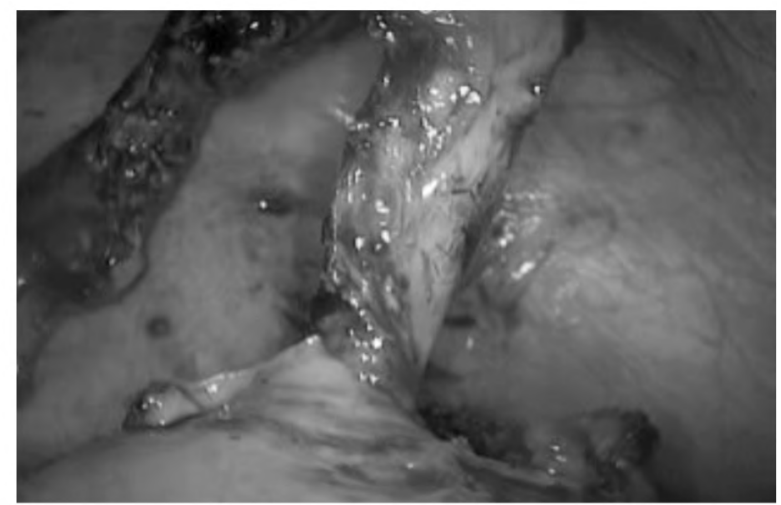

Fig. (4): Complete devascularization of the appendix till the base.

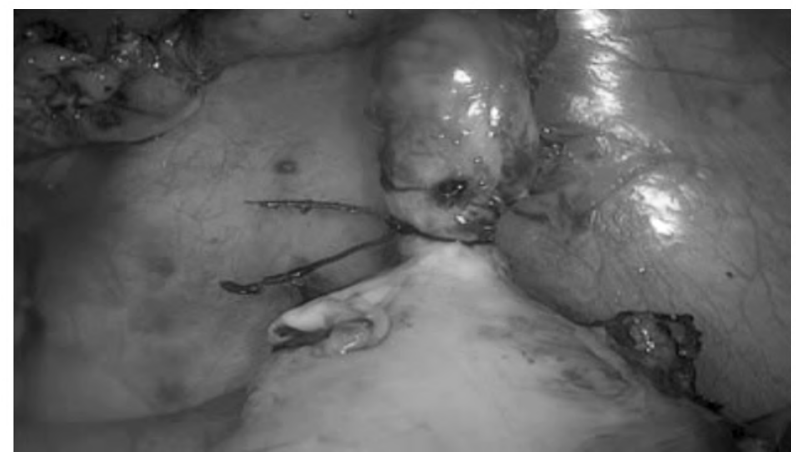

Fig. (6): Ligated first knot at the base of the appendix. 


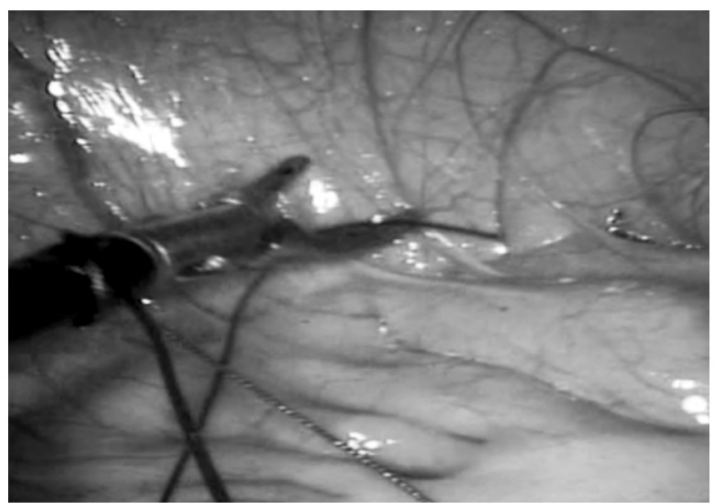

Fig. (7): Ligation of second knot intracorporeally.

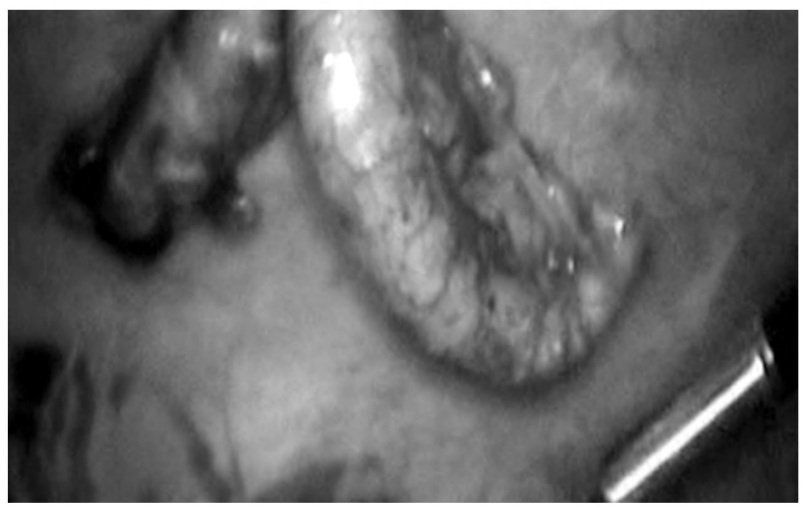

Fig. (9): Appendectomy completed.

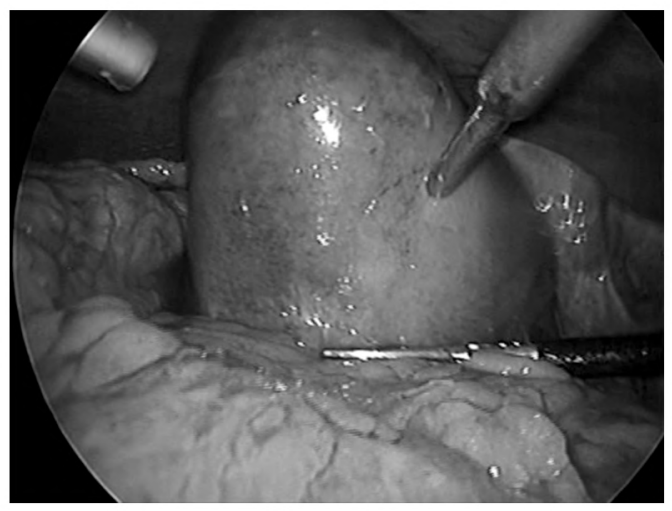

Fig. (11): Appendicular mass.

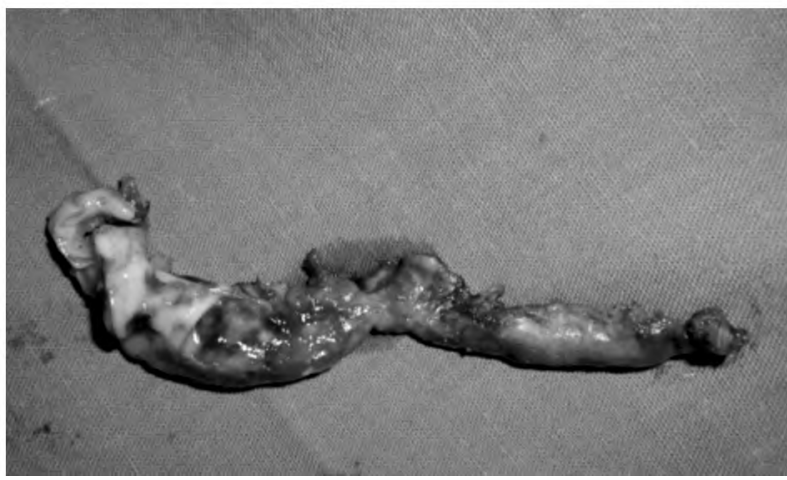

Fig. (13): Excised suppurative appendix with evident pyogenic membrane.

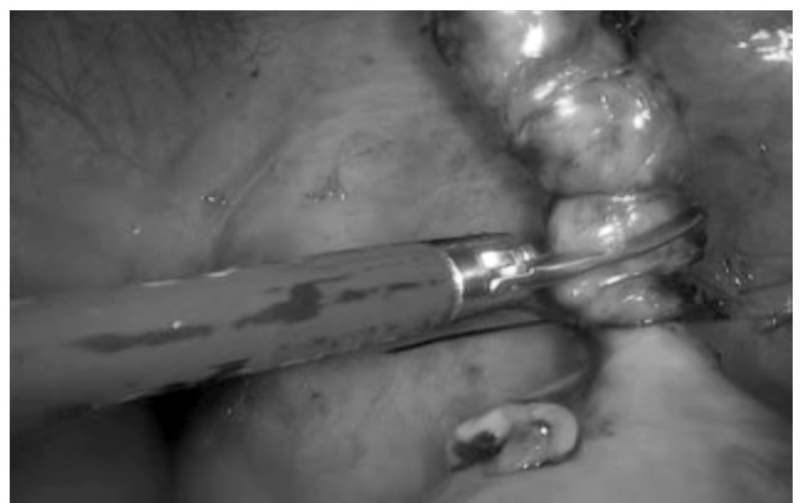

Fig. (8): Cutting the appendix using scissors.

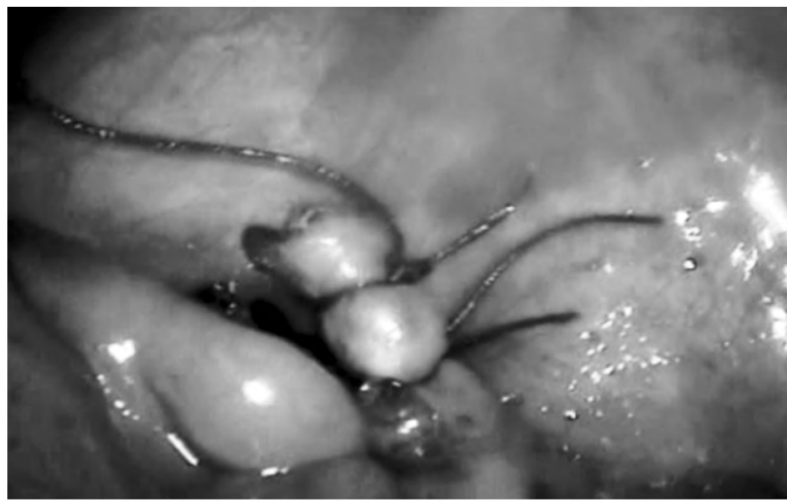

Fig. (10): Base secured with 2 vicryl ligatures.

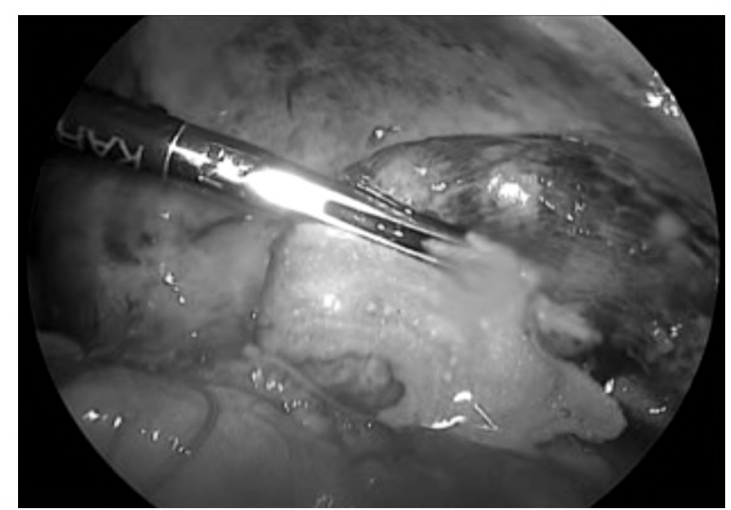

Fig. (12): Appendicular abscess showing pus.

\section{Post-operative management:}

Analgesics were given intramuscularly (pentazosine), as a suppository (diclofenac sodium), or orally (loxoprofen) as needed for the first 48 hours and, antibiotic regimen consisted of daily intravenous administration of (cefotiam, 80mg kg/24h) for 5 days intravenously and metronidazole (20 $\mathrm{mg} / \mathrm{kg} / 24 \mathrm{~h}$ ) for 5 days intravenously, oral antibiotics (cefuroxime + metronidazole) were continued for another 1 week.

Oral intake was started as soon as patient tolerated, when the bowel function became adequate. 
Patients were discharged when both oral intake and physical activity had recovered sufficiently.

\section{Follow-up of the patients:}

The patients were followed-up by clinical assessment for detection of the post-operative complications at the outpatient clinic after one week.

\section{Results}

I- Pre-operative results:

Table (1): Age distribution.

\begin{tabular}{lcc}
\hline Age distribution & Range (year) & Median \\
\hline Age & $4-18$ & 12 \\
\hline
\end{tabular}

Table (2): Sex distribution.

\begin{tabular}{llc}
\hline Sex & $\mathrm{N}$ & $\%$ \\
\hline Male & 27 & 67.5 \\
Female & 13 & 32.5 \\
\hline Total & 40 & 100 \\
\hline
\end{tabular}

Table (3): Laboratory investigations.

\begin{tabular}{lll}
\hline $\begin{array}{l}\text { Laboratory } \\
\text { investigations }\end{array}$ & \multicolumn{1}{c}{ Range } & \multicolumn{1}{c}{ Normal } \\
\hline WBCs & $13000-16900\left(\mathrm{~mm}^{3}\right)$ & $4000-11000\left(\mathrm{~mm}^{3}\right)$ \\
CRP & $6.8-96(\mathrm{mg} / \mathrm{L})$ & $0-6(\mathrm{mg} / \mathrm{L})$ \\
\hline
\end{tabular}

Table (4): Imaging studies (U/S).

\begin{tabular}{lll}
\hline Diagnosis & $\mathrm{N}$ & $\%$ \\
\hline Acute perforated appendicitis & 17 & 42.5 \\
Appendicular mass & 13 & 32.5 \\
Appendicular abcess & 8 & 20 \\
Intestinal obstruction & 2 & 5 \\
\hline Total & 40 & 100 \\
\hline
\end{tabular}

Table (5): Operative time.

\begin{tabular}{lcc}
\hline & Range $(\mathrm{min})$ & Mean \pm S.D \\
\hline Operative time & $36-92$ & $75.36 \pm 12.69$ minutes \\
\hline
\end{tabular}

Table (6): Histopathology.

\begin{tabular}{lcc}
\hline Histopathology & $\mathrm{N}$ & $\%$ \\
\hline Gangrenous appendicitis & 30 & 75 \\
Suppurative (Phlegmonous) appendicitis & 10 & 25 \\
\hline Total & 40 & 100 \\
\hline
\end{tabular}

Table (7): Hospital stay.

\begin{tabular}{lcl}
\hline & Range (day) & Mean \pm S.D \\
\hline Oral feeding & 1 to 5 & $2.9 \pm 1.8$ \\
Hospital stay & 3 to 8 & $5.03 \pm 1.758$ \\
\hline
\end{tabular}

\section{1- Imaging studies (U/S):}

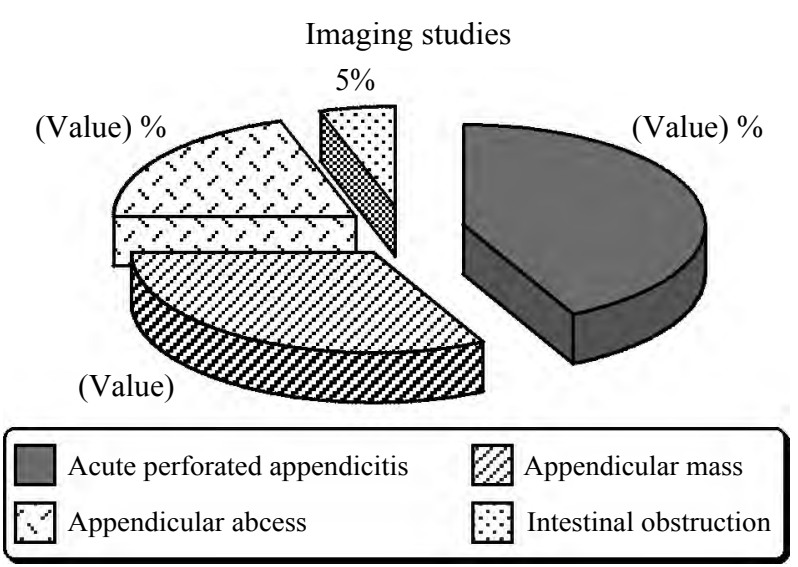

Fig. (14): Imaging studies.

Operative results:

- Intraoperative diagnosis:

The same as U/S fidings.

\section{- Devascularization time:}

The average time needed for devascularization of the appendix ranged from 15 to 42 minutes with a mean value $22.1 \pm 12.17$ minutes.

\section{- Knotting time:}

Knotting time ranged between 9 and 35 minutes with a mean value $16.12 \pm 6.52$ minutes.

\section{- Operative time:}

Operation time ranged between 36 and 92 minutes with a mean value $75.36 \pm 12.69$ minutes.

\section{- Drains:}

Drains were inserted in right side of pelvis in all patients.

\section{- Intraoperative complications:}

Two patients were converted to open appendectomy: The first case had appendicular mass and after meticulous dissection of the appendix it was retro cecal and plunged deeply. This case was converted to open appendectomy, through a McBurney; incision the tip of the appendix was delivered and the appendix was followed to the base which was ligated and the appendix was removed. The second case also had appendicular mass, uncontrolled bleeding occurred during dissection. This case was converted to open appendectomy, and the bleeding was controlled and the appendix was removed.

\section{- Histopathology:}

All samples were sent to Histopathology Department for further analysis. 


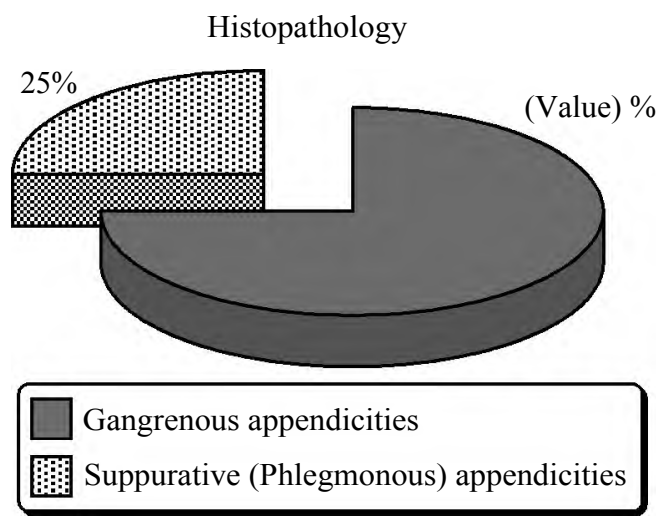

Fig. (15): Histopathology.

\section{Post-operative results:}

- Start of oral feeding:

The start of oral feeding ranged between one and five days with mean $2.9 \pm 1.8$ days.

\section{- Hospital stay:}

Hospital stay ranged between three and eight days with a mean $5.03 \pm 1.75$ days.

\section{- Post-operative complications:}

- Intraperitoneal collection:

In this study, there was one patient who suffered from post-operative small right iliac fossa hematoma proved by sonographic examination and was treated conservatively using antibiotics and sonographic follow-up.

\section{- Post-operative fever:}

In this study, five patients showed fever that was treated conservatively and disappeared within 24 hours.

\section{- Port site infection:}

In this study, two patients showed umbilical port site infection which was treated conservatively using antibiotics.

\section{Discussion}

Acute appendicitis is the most common cause of an acute abdomen requiring surgery, with a lifetime risk of about 7\% [5]. Since the introduction of laparoscopic appendectomy in 1983 by Kurt Semm [6], many questions were asked about this complicated procedure, including patients' safety [7], the cost benefits [8], the increased technological complexity [9] and the post-operative outcomes [10], leaving a wide area for researchers to find out.

Previous studies, including retrospective analyses of large databases or meta-analyses, concluded that laparoscopic appendectomy is associated with a reduction in wound infection rates and in-hospital stays as well as less post-operative pain with quicker functional recovery [7]. On the other hand, the laparoscopic approach is still controversial for complicated appendicitis in children [7]. This is related to a higher incidence of post-operative abdominal and wound infections [7]. Post-operative intra-abdominal abscess remains a major concern in laparoscopic appendectomy for perforated appendicitis [11,14].

Frazee and Bohannon were among the first to conclude that laparoscopic appendectomy is safe and beneficial for patients with complicated appendicitis [12]. Since then, a few retrospective studies discussed the feasibility and success of the laparoscopic approach, but it was not until Wullstein et al reported a large case series that the advantages of a minimally invasive technique for complicated appendicitis was established [13,14].

In this study we evaluated the feasibility and safety of laparoscopic appendectomy in cases of complicated appendicitis among pediatric patients.

This prospective study included 40 children with complicated acute appendicitis, all patients were managed by laparoscopic appendectomy within three days from start of symptoms.

Regarding age distribution, the age of the patients ranged from 4 to 18 years with median of 12 years, this is similar to Moraitis et al. study, in which age ranged from 4 to 18 years [18], Menezes et al., and Meguerditchian et al., where age ranged from 2 to 16 years $[15,22]$, Saquib et al., in which included age ranged from 3 to 12 years [16], and Ikeda et al., which ranged from 2 to 15 years with median of 9 years [20].

The sex distribution ratio found in this study was 2.07 males to 1 females which is similar to other studies as Menezes et al., study [15], Saquib et al., study [16], Wang et al., study [7] and Ikeda et al., study [20].

The mean total leukocyte count was $14100 \pm$ 2650 per $\mathrm{mm}^{3}$ with range between 13000 and $16900 \mathrm{~mm}^{3}$, this is in agreement with Hackam et al., study, who found that the mean total leukocyte count was 18000 per $\mathrm{mm}^{3}$ in his cases [19].

The serum C-reactive protein ranged between $6.8-96 \mathrm{mg} / \mathrm{dL}$ with a mean of $41.5 \pm 10.5 \mathrm{mg} / \mathrm{dL}$, this is in agreement with Ikeda et al., study, who found that the serum C-reactive protein ranged between 11 and $67.0 \mathrm{mg} / \mathrm{dL}$ with a mean of $38.4 \pm 11.6 \mathrm{mg} / \mathrm{dL}$ in [20]. 
There were seventeen patients with acute perforated appendicitis, thirteen patients with appendicular mass, eight patients with appendicular abscess, and two patients with intestinal obstruction, This is similar to Meguerditchian et al. study who reported gangrenous appendicitis in eighteen cases and perforated appendicitis in thirteen cases [22] Moraitis et al., study included three patients with complicated appendicitis (gangrenous or perforated) [18] and Ikeda et al. study, that included thirty one cases with phlegmonous appendicitis, twenty two patients with gangrenous or perforated appendicitis [20].

The operation time ranged between 36 to 92 minutes with mean of $75.36 \pm 12.69$ minutes. This is similar to Saquib et al., and Vahdad et al., studies in which the operation time ranged between 45120 minutes with mean of $70.2 \pm 11.3$ minutes $[16,21]$ This operative time was shorter than time reported in Ikeda et al., and Moraitis et al., studies which showed average time $87.3 \pm 9.1$ minutes, and $129.5 \pm$ 13.6 minutes respectively $[\mathbf{1 8 , 2 0 ]}$. This may be due to rising of experience with the rise in the learning curve of laparoscopic appendectomy.

Two cases were converted from laparoscopic to open appendectomy. The first case was an appendicular mass. Meticulous dissection was done, the appendix was retro cecal and plunging deeply. This case was converted to open appendectomy through a McBurney; incision the tip of the appendix was delivered and the appendix was followed to the base which was ligated and the appendix was removed. The second case was also with appendicular mass. Uncontrolled bleeding occurred during dissection. This case was converted to open appendectomy, the bleeding was controlled and the appendix was removed. In Saquib et al. study, they reported conversion in two patients because of difficulties in dissection and the consequent identification of the appendicular base [16]. Menezes et al., reported conversion in one patient with appendicular abcess due to difficulties in dissection of an appendicular abcess with a mass [15], Hackam et al., reported conversion in three patients due to difficulties in dissection [19], but in Lintula et al. study, there were no intraoperative complications [17].

There were two cases with intestinal obstruction from adhesions in this study. This is is similar to Vahdad et al., who reported two cases with intestinal obstruction [21].

Wound infection and intra-abdominal abscess are the commonest post-operative complications noted after appendectomy in children with complicated appendicitis [15]. In this study, there were three post-operative complications in the form of one intraperitoneal collection which was small right iliac fossa hematoma proved by sonographic examination and was treated conservatively with antibiotics and sonographic follow-up and two patients showed umbilical port site infection which was treated conservatively using antibiotics. This is in similar to Menezes et al. study who reported five patients with post-operative complications in the form of intra-abdominal collections in three cases and wound infections in two cases [15] Lintula et al., reported two major complications occuring in children with per appendicular masses, one child with an intrapelvic abscess, and the other has the tip of the appendix remained in situ after laparoscopic appendectomy [17,19], Hackam et al., reported three patients with abscesses, and one patient with a wound infection at the umbilical port site [19]. Ikeda et al., reported intra-abdominal abscess in four patients, wound infections in three patients, and stitch abscess in one patient [20] Meguerditchian et al., reported Intra-abdominal abscess in two cases, wound infection in three cases, umbilical granuloma in two cases, seroma in one case [22]. The post-operative complications in this study were few numbers due to meticulous work and complete aseptic conditions.

The mean length of post-operative hospital stay was $5.03 \pm 1.75$ days, this is similar to Meguerditchian et al., who reported postoperative hospital stay of $2.33 \pm 1.23$ day [22] . Hackam et al., found that the mean length of post-operative hospital stay was $5.95 \pm 1.56$ days [19], while Moraitis et al., found that the mean length of post-operative hospital stay was $3.58 \pm 1.98$ days in cases of complicated perforating appendicitis [18], and Menezes et al., found the mean length of post-operative hospital stay was $7.36 \pm 2.1$ days [15] .

As regards return to full enteral feeding, the mean duration of return to normal diet was $2.9 \pm 1.8$ days, this is comparable to Saquib et al., who reported the mean time until return to normal diet was $1.8 \pm 0.6$ days [16]

\section{Conclusions:}

Laparoscopic appendectomy is a safe, feasible and effective technique for complicated appendicitis such as mass, abscess and perforation in pediatric patients.

\section{References}

1- IONESCU S., ANDREI B., LICSANDRU E., IVANOV M. and IONESCU A.M.: Laparoscopic Treatment for 
Complicated Acute Appendicitis in Children, Junior Athletes. Chirurgia, 109 (4): 514, 2014.

2- NATARAJA R.M., TEAGUE W.J., GALEA J., MOORE L., HADDAD M.J., TSANG T. and CLARKE S.A.: Comparison of intraabdominal abscess formation after laparoscopic and open appendicectomies in children. J. of Pediatr. Surg., 47 (2): 317-21, 2012.

3- AZIZ O., ATHANASIOU T., TEKKIS P.P., PURKAYASTHA S., HADDOW J., MALINOVSKI V. and DARZI A.: Laparoscopic versus open appendectomy in children: A meta-analysis. Ann. Surg., 243 (1): 17, 2006.

4- KUTASY B., HUNZIKER M., LAXAMANADASS G. and PURI P.: Laparoscopic appendectomy is associated with lower morbidity in extremely obese children. Ped. Surg. Int., 27 (5): 533-6, 2011.

5- ROBERT O., FRAN O., KIRSTY K.O., TOM F. and BORISLAV D.D.: "The Alvarado score for predicting acute appendicitis: A systematic review", B.M.C. Med., Vol. 9, No. 1, p. 139, 2011

6- MUHAMMED A.M.: "Laparoscopic appendicectomy: Current status,” No. 4, pp. J. Emerg. Surg.; 393-402, 1997.

7- XIAOLIN W., WEN Z., XIAOJIN Y., JINFAN S., XUEFENG Z. and JIYAN Y.: "Complicated appendicitis in children: Is laparoscopic appendectomy appropriate? A comparative study with the open appendectomy-our experience,” J. Pediatr. Surg., Vol. 44, No. 10, pp. 19247, 2009.

8- VERNON A.H., GEORGESON K.E. and HARMON C.M.: "Pediatric laparoscopic appendectomy for acute appendicitis A cost analysis," J. Pediatr. Surg., pp. 75-9, 2004.

9- AVINASH N.S., GAURAV V.K. and PRADNYA A.S.: "Ergonomics in laparoscopic surgery", J. Pediatr. Surg., Vol. 6, No. 2, 2010.

10- SHERAZ R.M., SIMON B., RICHARD C., ALAN K. and JESSICA E. "Laparoscopic Versus Open Appendectomy for Complicated and Uncomplicated Appendicitis in Children," J. Gastrointest. Surg., pp. 1993-2004, 2012.

11- YOSHIRO T., SHUNICHIRO K., EIJI S.S.N. and YUJI S.: "Laparoscopic versus open surgery for complicated appendicitis in adults: A randomized controlled trial," Surg. Endosc., 2015.
12- FRAZEE R.C. and BOHANNON W.T.: "Laparoscopic appendectomy for complicated appendicitis.," Arch. Surg., Vol. 131, No. 5, pp. 503-9, May 1996.

13- C. WULLSTEIN, S. BARKHAUSEN, and E. GROSS "Results of laparoscopic vs. conventional appendectomy in complicated appendicitis.," Dis. Colon. Rectum., Vol. 44, No. 11, pp. 1700-5, Nov. 2001.

14- YAU K.K., SIU W.T., TANG C.N., YANG G.P.C. and LI M.K.W.: "Laparoscopic versus open appendectomy for complicated appendicitis.," J. Am. Coll. Surg., Vol. 205, No. 1, pp. 60-5, 2007.

15- MARIA M., LAXMAN D., MOHAMMED A., JULIANA H. and PREMPUR I.: (Laparoscopic appendectomy is recommended for the treatment of complicated appendicitis in children, J. Pediatr. Surg., 303-5, 2008.

16- SAQUIB M., AAYED M. and AL-BASSAM A.: Laparoscopic appendectomy is a favorable alternative for complicated appendicitis in children, Surg. Endosc., 257-9, 2007.

17-HANNU L., HANNU K., KARI V.P., MATTIESKELINEN K.F. and JOENSUU F.: Laparoscopy in Children With Complicated Appendicitis, J. Pediatr. Surg., 37 (9): 1317 20, 2002.

18- MORAITIS D., KINI S.U., ANNAMANENI R.K. and ZITSMAN J.L.: Laparoscopy in Complicated Pediatric Appendicitis, J.S.L.S., 310-3, 2004.

19- HACKAM D.J. and GAINES B.A.: Laparoscopic Appendectomy in Children with, J.M.A. Surg., 16 (2): 159-63, 2006.

20- IKEDA B.H., ISHIMARU Y., TAKAYASU H., OKAMURA K., KISAKI Y. and FUJINO J.: Laparoscopic Versus Open Appendectomy in Children With, J. Pediatr. Surg., 39 (11): 1680-5, 2004

21- VAHDAD M.R., TROEBS R., NISSEN M., BURKHARDT L.B., HARDWIG S. and CERNAIANU G.: Laparoscopic appendectomy for perforated appendicitis in children has complication rates comparable with those of open appendectomy. J. Pediatr. Surg., 48 (3): 555-61, 2013.

22- MEGUERDITCHIAN B.A., PRASIL P., CLOUTIER R. LECLERC S. and ROY G.: Laparoscopic Appendectomy in Children: A Favorable Alternative in Simple and Complicated Appendicitis, 695-8, 2002. 


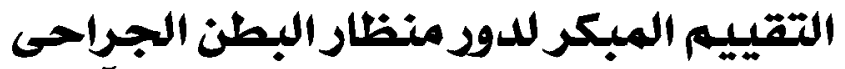

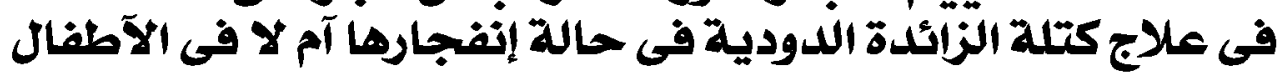

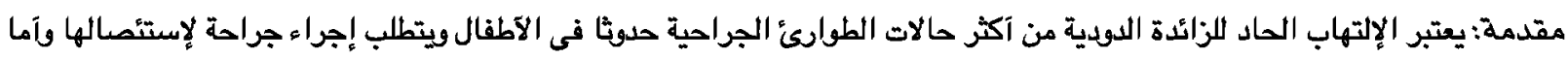

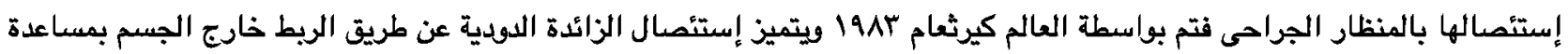

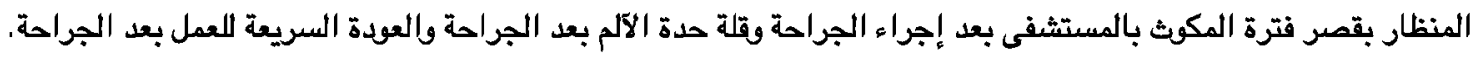

تهذف هذه الدراسة إلى تقييم إستئصال الزائدة الدودية في حالة الإلتهاب المضاعف بمساعدة المنظار خارج الجسم من حيث البساطة والسرعة والكناءة والتكلفة والنتائج الجمالية.

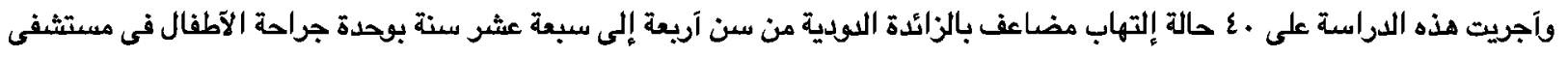

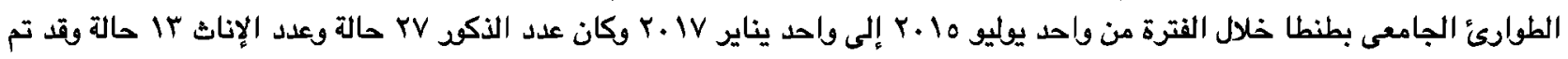

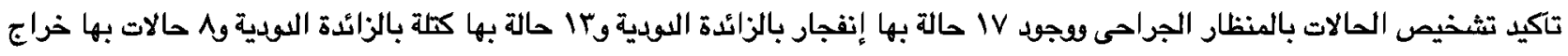
بالزائدة الدوية وحالتين فيهما إنسداد معوى.

كان متوسط الوقت لإجراء الجراحة بالمنظار ب. الح دقيقة دون مضاعفات جراحية عدا حالتين تم إستئصال الزائدة الدودية بالشق الجراحى.

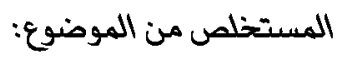

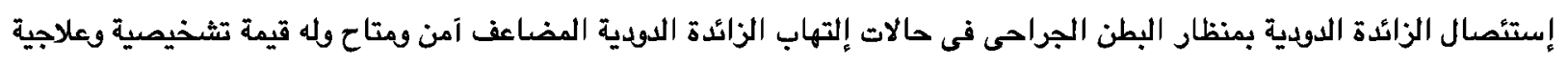
وذلك حيث البساطة والسرعة والكفاءة والتكلفة والنتائج الجمالية. 